ISSN 0258-7122

Bangladesh J. Agril. Res. 38(3): 505-513, September 2013

\title{
PANIKACHU (Calocasis esculenta L. Schott) CULTIVATION IN SOME SELECTED AREAS OF BANGLADESH: AN AGRO-ECONOMIC PROFILE
}

\author{
M. A. HAque ${ }^{1}$, M. A. MonaYem Miah' ${ }^{2}$, S. $\operatorname{HosSAIN}^{3}$ AND A. N. LUNA
}

\begin{abstract}
Panikachu is a nutritious vegetable contributing to the total supply of vegetables during the summer in Bangladesh. Many farmers cultivate this crop from their innovative ideas. Researchers are unable to formulate adequate research design for its varietal improvement and technology packages. Therefore, the study was conducted in two panikachu growing districts, namely Joypurhat and Jessore during February 2011 to know the profitability of panikachu cultivation. In total, 100 panikachu farmers were selected of which 50 farmers from each area were selected randomly to collect primary data. The results indicated that the costs of panikachu cultivation were Tk. 2,67,726 and Tk. 1,84,530 per hectare on total cost and variable cost basis, respectively. The major share of total cost was for human labour $(45 \%)$, land use $(17 \%)$, and fertilizer $(15 \%)$. The yield for rhizome and stolon were 24.94 tons and 23.29 tons per hectare. The gross margin and net returns were Tk. 2,06,058 and Tk. 1,22,862 per hectare. The benefit cost ratios was 1.46. Human labour, manure, urea, TSP, MoP, insecticides, and irrigation had positive effect on the yield of panikachu. Lack of technical knowledge about improved cultivation practices, non-availability of HYV seedling, and low price of product were major constraints to panikachu cultivation.
\end{abstract}

Keywords: Panikachu, input use pattern, gross margin, net return, BCR.

\section{Introduction}

Panikachu (Calocasis esculenta L. Schott) is an important edible aroid in Bangladesh. It contributes to the total supply of bulky vegetables during the summer when the supply of other vegetables becomes scarce in the market. Panikachu is generally grown almost all over Bangladesh, but its production is more concentrated in the districts of Chittagong, Norail, Serajgonj, Bogra, Joypurhat, Pabna, Tangail, Dinajpur, Jessore, Jamalpur, Sylhet, and Kishoregonj (BBS, 2008). As a root crop, it compares favourably in terms of nutritional value with other root crops, such as cassava, yam, sweet potato, and other edible aroids. It contains over 25\% carbohydrates (Rashid and Danichi, 1979). Most parts of this vegetable, such as leaves, stolon, rhizome, and stems contain protein, carbohydrate, and calorie. The soil and climatic condition of Bangladesh are highly favourable for panikachu cultivation.

${ }^{1}$ Principal Scientific Officer, ${ }^{2}$ Senior Scientific Officer, ${ }^{3}$ Chief Scientific Officer, Agricultural Economics Division, and ${ }^{4}$ MSS Student, Department of Economics, Lalmatia Mohilla University College, Dhaka. 
The demand of panikachu is increasing day by day, but very little attempt has been made for its technological development for higher production in any part of our country. Farmers are cultivating this crop from their innovative ideas regarding adaptability of local cultivars, fertilizer dose, and other agronomic practices. Not only that, due to lack of information at farmers' level on panikachu production, the researchers are facing difficulties to formulate adequate research design for its varietal improvement as well as for the development of a complete technology package. With this view in mind, the present study has been designed with the following objectives:

(i) To know the existing agronomic practices of panikachu cultivation at farm level;

(ii) To estimate the economic profitability of panikachu cultivation;

(iii) To determine the input - output relationship of panikachu cultivation; and

(iv) To find out the constraints to its higher production.

\section{Materials and Method}

Sampling technique: A multi-stage sampling technique was followed in this study to select study areas and sample farmers. In first stage of sampling, two panikachu growing districts Joypurhat and Jessore were selected purposively. In the second stage, Pachbibi upazila under Joypurhat District and Bagarpara upazila under Jessore District were selected for sample survey. In the third stage, a complete list of panikachu growers were collected from each upazila and finally a total of 100 panikachu farmers taking 50 farmers from each upazila were selected by random sampling technique.

Method of data collection: Data for the present study were collected from sample panikachu farmers through face to face interview method using a pretested interview schedule. Field level data were colleted by the researcher with the help of trained enumerators for the period of February 2011.

Analytical techniques: Both fixed cost and variable cost were taken into account in calculating cost of panikachu cultivation. Land use cost was calculated on the basis of per year existing lease value of land. The profitability of panikachu cultivation was examined on the basis of gross margin, net return, and benefit cost analysis. The collected data were edited, summarized, tabulated, and analyzed to fulfill the objectives of the study. Tabular method using descriptive statistics was mostly used in the study. Cobb-Douglas production function model 
was used to estimate the contribution of factors to panikachu cultivation. The functional form of the Cobb-Douglas production function model is given below:

$$
\mathrm{Y}=\mathrm{AX}_{1}{ }^{\mathrm{b} 1} \mathrm{X}_{2}^{\mathrm{b} 2}
$$

The production function was converted to logarithmic form so that it could be solved by least square method i.e.

$$
\ln Y=\ln a+b_{1} \ln X_{1}+b_{2} \ln X_{2}+\ldots \ldots \ldots \ldots \ldots \ldots \ldots b_{n} \ln X_{n}+U_{i}
$$

The empirical production function model was the following:

$\ln Y=a+b_{1} \ln X_{1}+b_{2} \ln X_{2}+b_{3} \ln X_{3}+b_{4} \ln X_{4}+b_{5} \ln X_{5}+b_{6} \ln X_{6}+b_{7} \ln X_{7}+b_{8}$ $\ln \mathrm{X}_{8}+\mathrm{U}_{\mathrm{i}}$

Where,

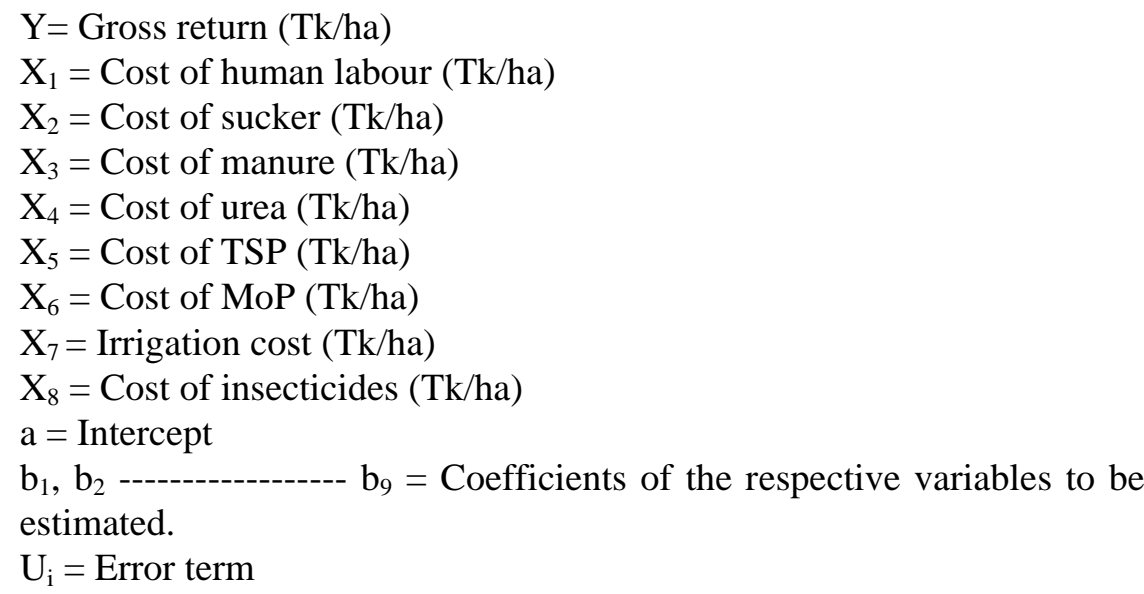

\section{Results and Discussion}

\section{Agronomic practices}

All the agronomic practices are shown in Table 1. The farmers ploughed 5.5 times followed by laddering of 2.5 times for the preparation of panikachu land. Panikachu is being grown in Bangladesh during the kharif season. In India, the planting is normally done in the rainy season and it could be grown any time if irrigation facilities are available (Bose and Som, 1996). But in the study area, the planting time was February to March. Panikachu propagated by suckers and sucker was planted in rows. The farmers in the study areas performed some intercultural operations like weeding, spraying, and irrigating the crop. The number of weedings, insecticide spraying, and irrigation per farm were 11,9, and 5.5 , respectively. The harvesting time of stolen started in the month of May and continued up to the month of November. The harvesting time of rhizome was November to December. 
Table 1. Agronomic practices in panikachu cultivation in different study areas.

\begin{tabular}{lcccc}
\hline Agronomic practices & Joypurhat & Jessore & All areas \\
\hline No. of ploughings & 5 & 6 & 5.5 \\
No. of ladderings & 2 & 3 & 2.5 \\
Time of plantings & February-March & February -March & February -March \\
No. of weedings & 12 & 10 & 11 \\
No. of irrigations & 8 & 10 & 9 \\
No. of sprayings & 6 & 5 & 5.5 \\
Time of harvesting: & & & \\
\multicolumn{1}{c}{ Rhizome } & November- & November- & November- \\
\multicolumn{1}{c}{ Stolen } & December & December & December \\
& May-November & May-November & May-November \\
\hline
\end{tabular}

\section{Input use pattern}

The number of human labour used for cultivating panikachu was 808 man days per hectare. The use of human labour was found higher in Joypurhat than in Jessore area. The cost of land preparation was Tk. 6564 per hectare (Table 2). The average number of suckers was 23275 per hectare, which was lower than the recommended rate of sucker (37000/ha). The farmers in the study area used 11.49 tons of manure per hectare. The farmers also used chemical fertilizers like urea, TSP, MoP at the rate of $889 \mathrm{~kg}, 624 \mathrm{~kg}, 268 \mathrm{~kg}$ per hectare which were higher than the recommended fertilizer dose*. The reason of using higher dose of chemical fertilizer was might be due to ignorance of the farmer.

Table 2. Input use pattern of panikachu cultivation in different study areas.

\begin{tabular}{lccc}
\hline Inputs & Joypurhat & Jessore & All areas \\
\hline Human labour (man-day/ha) & 817 & 799 & 808 \\
$\quad$ Family & 271 & 247 & 259 \\
$\quad$ Hired & 546 & 552 & 549 \\
Land preparation cost (Tk/ha) & 6081 & 7047 & 6564 \\
Suckers (No./ha) & 22877 & 23674 & 23275 \\
Organic manure (kg/ha) & 19535 & 3459 & 11497 \\
Fertilizers(kg/ha) & & & \\
$\quad$ Urea & 950 & 828 & 889 \\
TSP & 640 & 607 & 624 \\
MP & 306 & 230 & 268 \\
Zipsum & 232 & 320 & 276 \\
$\quad$ Zinc Sulphate & 28 & 105 & 66 \\
\hline
\end{tabular}

\footnotetext{
* The recommended doses of urea, TSP and MoP are $150 \mathrm{~kg} / \mathrm{ha}, 125 \mathrm{~kg} / \mathrm{ha}$ and $175 \mathrm{~kg} / \mathrm{ha}$, respectively (TCRC, 2008).
} 


\section{Cost of panikachu cultivation}

The cost of panikachu cultivation included different variables and fixed costs. The cost of hired labour, land preparation, suckers, organic manure, chemical fertilizers, insecticides and irrigation, interest on operating capital were considered as variable costs. The cost of family labour and land use were considered as fixed costs. The costs of panikachu cultivation were Tk. 267726 and Tk. 184530 per hectare on full cost and variable cost basis, respectively. The major share of total cost was for human labour (45\%), land use (17\%) and fertilizer (15\%). The cost of cultivation of panikachu in Joypurhat was found higher than Jessore due to higher cost of land use, sucker and human labour cost (Table 3).

Table 3. Cost of cultivation of panikachu in different study areas.

\begin{tabular}{l|c|c|c}
\multicolumn{4}{c}{ (Figure in Tk./ha) } \\
\hline Items & Joypurhat & Jessore & All areas \\
\hline A. Variable costs & $\mathbf{1 8 5 3 0 8 ( 6 8 )}$ & $\mathbf{1 8 3 7 5 2}(\mathbf{6 9})$ & $\mathbf{1 8 4 5 3 0 ( 6 9 )}$ \\
$\quad$ Land preparation & $6081(2)$ & $7047(3)$ & $6564(2)$ \\
Hired labour & $82025(30)$ & $82833(31)$ & $82429(31)$ \\
Suckers & $17158(6)$ & $11836(4)$ & $14497(5)$ \\
Organic manure & $9767(4)$ & $1729(1)$ & $5748(3)$ \\
Fertilizers: & $38589(14)$ & $42570(16)$ & $40579(15)$ \\
Urea & 11396 & 10513 & 10954 \\
TSP & 15371 & 15913 & 15642 \\
MP & 7051 & 5708 & 6380 \\
Zipsum & 1396 & 1766 & 1581 \\
Zinc Sulphate & 3374 & 8670 & 6022 \\
Insecticides/pesticides & $6501(2)$ & $5359(2)$ & $5930(2)$ \\
Irrigation & $15668(6)$ & $22644(8)$ & $19156(7)$ \\
Int. on operation capital & $9518(4)$ & $9731(4)$ & $9624(4)$ \\
B. Fixed cost & $\mathbf{8 5 6 2 4 ( 3 2 )}$ & $\mathbf{8 0 7 6 9 ( 3 1 )}$ & $\mathbf{8 3 1 9 6 ( 3 1 )}$ \\
Land use cost & $44909(17)$ & $43711(17)$ & $44310(17)$ \\
Family labour & $40715(15)$ & $37057(14)$ & $38886(14)$ \\
C. Full cost (A+B) & $\mathbf{2 7 0 9 3 2 ( 1 0 0 )}$ & $\mathbf{2 6 4 5 2 1 ( 1 0 0 )}$ & $\mathbf{2 6 7 7 2 6 ( 1 0 0 )}$ \\
\hline
\end{tabular}

Figures within parenthesis indicate $\%$ of total cost

Note: Price of fertilizers: Cowdung $=$ Tk. $0.50 / \mathrm{kg}$, Urea $=$ Tk.12 $/ \mathrm{kg}, \mathrm{TSP}=\mathrm{Tk} .25 / \mathrm{kg}$ and $\mathrm{MoP}=$ Tk. $23.8 / \mathrm{kg}$. 


\section{Profitability of panikachu cultivation}

Yield data included some marketable portion of petiole with rhizome and stolon. The average yield for rhizome and stolon were 24.94 tons and 23.29 tons per hectare, respectively. The yield of rhizome $(25.20 \mathrm{t} / \mathrm{ha})$ was found higher in Jessore than Joypurhat mainly due to better land preparation and more population of sucker. On the other hand, the yield of stolon (23.74 t/ha) was found higher in Joypurhat than Jessore due to higher use of manure and fertilizers (Table 4). The gross return of panikachu cultivation was estimated to be Tk. 390588 per hectare. The gross margin and net return were Tk. 206058 and Tk. 122862 per hectare. Gross margin and net return were found higher in Joypurhat than Jessore due to higher gross return. The benefit cost ratios were 1.46 and 2.11 on full cost and variable cost basis respectively (Table 5).

Table 4. Yield of panikachu in different study areas.

\begin{tabular}{l|c|c|c|c}
\hline Study area & $\begin{array}{c}\text { Wt of rhizome } \\
\text { (g/plant) }\end{array}$ & $\begin{array}{c}\text { Wt of stolon } \\
\text { (g/plant) }\end{array}$ & $\begin{array}{c}\text { Yield of } \\
\text { rhizome (t/ha)* }\end{array}$ & $\begin{array}{c}\text { Yield of } \\
\text { stolon }(\mathrm{t} / \mathrm{ha})\end{array}$ \\
\hline Joypurhat & 1250 & 1202 & 24.68 & 23.74 \\
Jessore & 1149 & 1039 & 25.20 & 22.84 \\
All areas & 1199 & 1121 & 24.94 & 23.29 \\
\hline
\end{tabular}

*Weight of rhizome including marketable portion of petiole

Table 5. Profitability of panikachu production in different study areas.

\begin{tabular}{l|c|c|c}
\multicolumn{1}{c}{ Items } & Joypurhat & Jessore & All areas \\
\hline Gross return: & 394602 & 386573 & 390588 \\
Rhizome & 33057 & 37809 & 35433 \\
Stolon & 353264 & 342694 & 347979 \\
Sucker & 8281 & 6070 & 7176 \\
Total variable cost & 185308 & 183752 & 184530 \\
Total cost & 270932 & 264521 & 267726 \\
Gross margin & 209294 & 202821 & 206058 \\
Net return & 123670 & 122052 & 122862 \\
Benefit cost ratio & & & \\
Full cost basis & 1.47 & 1.46 & 1.46 \\
Variable cost basis & 2.12 & 2.10 & 2.11 \\
\hline
\end{tabular}

\section{Factors affecting panikachu yield}

In order to determine the contribution of some inputs for panikachu production, Cobb- Douglas production function was used. The estimated values of co- 
efficient and related statistics of Cobb- Douglas production function are presented in Table 6. It is clear from the model that the co-efficient of human labour, urea, TSP, and insecticides were positively significant at $1 \%$ level indicate that $1 \%$ increase in human labour, urea, TSP, and insecticides cost would increase the return of panikachu by $0.001 \%, 0.005 \%, 0.002 \%$, and $0.009 \%$, respectively, keeping other factors constant. The co-efficient of manure was positively significant at $5 \%$ level indicated that $1 \%$ increase in manure cost would increase the return of panikachu by $0.007 \%$ keeping other factors constant. The co-efficient of $\mathrm{MoP}$ and irrigation were positively significant at $10 \%$ level indicating that $1 \%$ increase in MoP and irrigation cost would increase the return of panikachu by $0.007 \%$ and $0.004 \%$, respectively, keeping other factors constant.

Table 6. Estimated coefficients and their related statistics of production function for panikachu cultivation.

\begin{tabular}{lcc}
\hline \multicolumn{1}{c}{ Explanatory variables } & Co- efficient & t-value \\
\hline Constant $(\mathrm{a}):$ & $482680^{* * *}$ & 5.48 \\
Human Labour $\left(\mathrm{X}_{1}\right)$ & $0.001^{* * *}$ & 6.11 \\
Sucker $\left(\mathrm{X}_{2}\right)$ & $0.003 \mathrm{~ns}$ & 1.02 \\
Manure $\left(\mathrm{X}_{3}\right)$ & $0.007^{* * *}$ & 2.44 \\
Urea $\left(\mathrm{X}_{4}\right)$ & $0.005^{* * *}$ & 4.83 \\
$\mathrm{TSP}\left(\mathrm{X}_{5}\right)$ & $0.002^{* * *}$ & 4.04 \\
MP $\left(\mathrm{X}_{6}\right)$ & $0.007^{*}$ & 1.84 \\
Irrigation $\left(\mathrm{X}_{7}\right)$ & $0.004^{*}$ & 1.93 \\
Insecticides $\left(\mathrm{X}_{8}\right)$ & $0.009^{* * *}$ & 12.48 \\
$\mathrm{R}^{2}$ & 0.64 & \\
$\mathrm{~F}$ & $82.072^{* * *}$ & \\
\hline
\end{tabular}

Note: $* * *, * *$ and $*$ indicate significant at $1 \%, 5 \%$ and $10 \%$ level, respectively.

The value of coefficient of determination $\left(\mathrm{R}^{2}\right)$ was 0.64 , which indicated that around $64 \%$ of the variation in yield was explained by the independent variables included in the model. The F-value was found 82.07 which was significant at $1 \%$ level implying that the variation of yield mainly depends on the explanatory variables included in the model.

\section{Constraints to panikachu cultivation}

The respondent farmers were asked about the constraints of panikachu cultivation. In this regard, more than one answer was given by the respondents. The answer was arranged in rank value. It was observed that lack of technical knowledge about improved cultivation practices was the first ranked constraint to 
panikachu cultivation followed by non-availability of HYV seedling at proper time, low market price, and infestation of insects and diseases (Table 7).

Table 7. Constraints of panikachu cultivation in different study areas.

\begin{tabular}{ll|c|c|c}
\hline \multicolumn{2}{c}{ Constraints } & \multicolumn{3}{c}{ Rank value } \\
\cline { 3 - 5 } & Joypurhat & Jessore & All areas \\
\hline 1. $\begin{array}{l}\text { Lack of technical knowledge } \\
\text { improved cultivation practices }\end{array}$ & 1 & 1 & 1 \\
2. Non- availability of HYV seedling & 2 & 2 & 2 \\
3. Low price of product & 3 & 3 & 3 \\
4. Infestation of insects and diseases & 1 & 4 & 4 \\
\hline
\end{tabular}

\section{Conclusion}

From the above discussions, it may be concluded that panikachu is a profitable crop at farm level. The farmers in the study areas followed traditional but innovative techniques for producing this crop and used local improved variety. Human labour, manure, urea, TSP, MoP, irrigation, and insecticides had positive effect on the yield of panikachu in the study areas. Lack of technical knowledge about improved cultivation practices of panikachu, non-availability of HYV seedling, low price of product, and infestation of insects and diseases were major constraints in panikachu cultivation.

\section{Recommendations}

Based on the findings of the study, the following recommendations were undertaken for the improvement of panikachu cultivation:

1) Farmers' training on panikachu cultivation should be organized by government and non-government organizations to develop technical knowledge of the farmers about improved cultivation practices of panikachu.

2) High yielding varieties of panikachu seedling should be made available to the farmers' level at proper time. For this reason, Government should encourage BARI scientists to develop HYV seedling of panikachu.

3) The price of stolon and rhizome of panikachu was very low in the study areas mainly due to some fraudulent traders. To overcome this problems, cooperative marketing system should be established among the farmers to sell their products.

4) More intensive research should be undertaken by the BARI scientists to develop disease and insect-pest resistant seedling in the near future. 


\section{References}

Anonymous. 2008. Root Crops Development in Bangladesh, Annual Report, Tuber Crops Research Centre, Bangladesh Agricultural Research Institute, Gazipur, Pp. 30-36.

BBS. 2008. Yearbook of Agricultural Statistics of Bangladesh, Bangladesh Bureau of Statistics, Ministry of Planning, GOB, Dhaka.

Bose, T.K. and M.G. Som. 1996. Vegetable crops in India. Naya Prokash, Calclutta, 6, India, Pp. 722-31.

Rashid, M.M. and H.J. Danichi. 1979. Chemical composition of nine edible aroid cultivars of Bangladesh. Scientia Horticulture 10: 1127-34. 